ORIGINAL ARTICLE

AFRICAN JOURNAL OF CLINICAL AND EXPERIMENTAL MICROBIOLOGY AJCEM/21308

COPYRIGHT 2013 http;//dx.doi.org/10.4314/ajcem.v14i1.9

JANUARY2013 ISBN 1595-689X VOL 14(1) 2013

AFR. J. CLN. EXPER. MICROBIOL 14(1): 40-44

-http://www.ajol.info/journals/ajcem

\title{
RUBELLA IgG ANTIBODY AMONG NIGERIAN PREGNANT WOMEN WITHOUT VACCINATION HISTORY
}

${ }^{1}$ Adewumi, M.O., ${ }^{2}$ Olusanya, R.B., ${ }^{2}$ Oladunjoye, B.A. \& ${ }^{1}$ Adeniji, J.A.

Departments of Virology, College of Medicine ${ }^{1}$, and Microbiology ${ }^{2}$ University of Ibadan;

Correspondence: Department of Virology, College of Medicine, University College Hospital, Ibadan, Nigeria. Telephone: +234 8060226655 E-Mail: adewumi1@hotmail.com

\begin{abstract}
Rubella is a vaccine-preventable viral infection, its aetiologic agent; rubella virus was identified as human teratogen capable of causing a spectrum of birth defects described as congenital rubella syndrome (CRS). Despite the availability of safe and effective vaccines, significant proportion of the population remains susceptible to rubella infection in developing countries. More significantly, such developing countries including Nigeria have not demonstrated adequate commitment to preventive vaccination; a panacea for intervention. Consequently, this study was designed to determine the prevalence of anti-rubella IgG among pregnant women to ascertain the proportion of susceptible population. A total of 273 consenting rubella vaccine naïve antenatal clinic attendees aged 15-42 years (Median age $=28$ years) were randomly selected and their sera analyzed for qualitative and quantitative anti-rubella IgG detection. Overall, $244 / 273(89.4 \%)$ pregnant women enrolled in this study had protective level (Titre $=>10 \mathrm{IU} / \mathrm{mL}$ ) of anti-rubella IgG $($ Median Titre $=165 \mathrm{IU} / \mathrm{mL}$; Range $=<10->250 \mathrm{IU} / \mathrm{mL}$ ), while, 29/273 $(10.6 \%)$ of the study population lack protective antibody titre ( $\mathrm{OD}=\leq \mathbf{1 0} \mathrm{IU} / \mathrm{mL}$ ). Results confirm previous reports of exposure, infection, and continuous circulation of rubella virus in Nigeria. It emphasizes the need for improved and continuous surveillance for rubella and CRS cases, prompt vaccination of vulnerable populations, and evaluation of health policies to achieve immunization and ultimately ensure control/elimination of rubella virus in Nigeria and beyond.
\end{abstract}

Keywords: Rubella, Pregnancy, Antibody, Congenital Rubella Syndrome, Nigeria

\section{INTRODUCTION}

Rubella is a vaccine-preventable viral infection of the skin and lymph nodes often culminating in a mild rash. The aetiologic agent is a positive sense single-stranded RNA rubella virus in the family Togaviridae $[1,2]$. The virus has been identified as a human teratogen capable of causing a spectrum of birth defects often collectively referred to as congenital rubella syndrome $[3,4,5]$ or death $[6$, 7] of a developing foetus, especially if the viral infection is acquired in the early months, that is first trimester of pregnancy $[2,8,9,10]$.

In spite of the availability of a safe and effective vaccine against rubella, an estimated over 100,000 infants are born with congenital rubella syndrome annually [6, 11, 12]. Additionally, approximately 3 to $23 \%$ of adults remain susceptible to rubella virus infection in various countries and areas, although studies have shown that a large proportion of unimmunized populations in areas where rubella is endemic are infected and become seropositive before puberty $[13,14,15,16]$.

Dwyer et al., (2001) noted that about $10-25 \%$ of non-immunized women of childbearing age are susceptible to rubella virus infection [17]. Furthermore, studies have shown that $80-90 \%$ of babies born to women infected with rubella virus during the first trimester of gestation experience birth defects $[9,18]$. Humans are the only known reservoir for rubella virus; hence, its maintenance requires continuous access to a susceptible population. Equally, elimination of rubella and CRS with an effective vaccination program in some countries [19] is an evidence of achievable intervention plan for rubella virus and the disease.

Despite the reality of preventive rubella vaccine, routine screening and preventive vaccination against rubella virus for women and children have not been incorporated into the antenatal care and National Program on Immunization (NPI) in Nigeria. Also, rubella infection and CRS are not reportable diseases in the country. Therefore, to achieve intervention in Nigeria and beyond, there is the need to assess current situation of rubella infection especially among at risk population. Such information is essential to demonstrate the need for government to support preventive vaccination, especially among women of childbearing age, and surveillance for CRS to 
facilitate prompt intervention. Therefore, to achieve the aforementioned, this study was designed to determine the prevalence of antirubella IgG among pregnant women in order to ascertain the proportion of susceptible population.

\section{MATERIALS AND METHODS STUDY LOCATION}

This study was carried out among pregnant women attending Ade-Oyo Maternity Hospital in Ibadan, south western, Nigeria. The hospital is located in a densely populated centre of the city and serves pregnant women of varied educational status from different parts of the city. The antenatal clinic records an average of $380 \pm 20$ new patients per week.

\section{ENROLMENT OF THE STUDY POPULATION}

Participants for this study were enrolled in July, 2010. After approval was obtained from the Hospital Management Board, each prospective participant was counselled, and only consenting clinic attendees were enrolled for the study. During the enrolment period, the ante-natal clinic was visited five times. Blood samples were collected from a total of 273 consenting pregnant women (Median age $=28$ years; Range $=15-42$ years) at the point of registration for the antenatal clinic. The participants were mostly women of low educational status, thus could not provide any proof or record of rubella vaccination. Rubella vaccines are currently available in Nigeria at a cost, thus limited to the elites who appreciate the importance of preventive vaccination.

\section{SAMPLE COLLECTION, PREPARATION AND STORAGE}

About 5 millilitres of blood specimen was collected by venepuncture from each consenting pregnant woman into a sterile container free of anticoagulants or preservatives. Each specimen was labelled with the date of collection and laboratory identity number. Samples were transported to the laboratory immediately in a cold box with frozen ice packs to achieve condition of about $4-8^{\circ} \mathrm{C}$. Serum samples were separated by low-speed centrifugation at $500 \times \mathrm{g}$ for 5 minutes, or direct removal of the serum using a sterile disposable pipette after retraction of the clot. The serum was transferred into labelled sterile cryovials and stored at $-20^{\circ} \mathrm{C}$ until ready for analysis.

\section{LABORATORY ANALYSIS}

The laboratory analysis was carried out in the Department of Virology, College of Medicine,
University College Hospital, Ibadan. The samples were analyzed for qualitative and quantitative detection of anti-rubella IgG antibody using

DIA.PRO ${ }^{\circledR}$ Diagnostic Bioprobes s.r.l. (Sede legale: Via Lucio Giunio Columella, 31-20128-Milano)

Enzyme Immunoassay in accordance with the manufacturer's description. The test kit has diagnostic sensitivity and specificity performance of $>98 \%$.

\section{STATISTICAL ANALYSIS}

Demographic features of the study population were described. Also, results of the study were analyzed using the statistical package for the social sciences (SPSS) version 15.0 windows, and p-value $<0.05$ was considered statistically significant.

\section{RESULTS}

Overall, 244/273 (89.4\%) pregnant women enrolled in this study had protective level (Titre = $>10 \mathrm{IU} / \mathrm{mL}$ ) of anti-rubella IgG (Median Titre $=$ $165 \mathrm{IU} / \mathrm{mL}$; Range $=<10->250 \mathrm{IU} / \mathrm{mL}$ ), while, $29 / 273(10.6 \%)$ of the study population lack protective antibody titre $(\mathrm{OD}=\leq 10 \mathrm{IU} / \mathrm{mL}$ ). Nine out of the twenty-nine $(31.0 \%)$ women in the later category had no detectable anti-rubella IgG antibody (OD < $0 \mathrm{IU} / \mathrm{mL}$. Analysis by age shows highest and lowest rates of seropositivity in age groups $>40$ and $31-40$ years respectively (Table 1). However, no statistically significant difference $(p=0.906)$ was recorded in the rates of seropositivity to rubella virus infection by age.

\section{DISCUSSION}

Previous studies [20, 21, 22, 23, 24] have reported varied prevalence rates of anti-rubella IgG among Nigerian population including pregnant women. More significantly, in 2002 Bukbuk et al., [25] in a study among non-immunized pregnant women in Maiduguri, north eastern Nigeria reported 54.1\% prevalence of rubella-specific IgG antibody. Consequently, detection of anti-rubella IgG in $89.4 \%$ of pregnant women without history of rubella vaccination in this study corroborates findings from previous studies in the country [20, $21,22,23,24,25]$. Furthermore, detection of antirubella IgG among rubella pregnant women without vaccine history is an indication of previous exposure and subclinical or clinical infection by rubella virus. Therefore, this confirms continuous circulation of rubella virus in a country where preventive rubella vaccine is only available for the informed adult population at a cost. Additionally, it confirms earlier reports [24, 26, 27] that rubella virus may have been circulating continuously in Nigeria but for paucity of data on its burden. 
TABLE 1: RUBELLA IgG ANTIBODY AMONG PREGNANT WOMEN OF DIFFERENT AGE GROUPS ATTENDING ANTE-NATAL CLINIC IN IBADAN, NIGERIA

\begin{tabular}{llll}
\hline AGE (YEAR) & NUMBER TESTED (\%) & NUMBER POSITIVE (\%) & $\begin{array}{l}\text { NUMBER } \\
(\%)\end{array}$ \\
\hline$\leq 20$ & $30(11.0)$ & $27(90)$ & $3(10)$ \\
$21-30$ & $170(62.3)$ & $152(89.4)$ & $18(10.6)$ \\
$31-40$ & $69(25.3)$ & $61(88.4)$ & $8(11.6)$ \\
$>40$ & $4(1.5)$ & $4(100.0)$ & $0(0)$ \\
\hline TOTAL & $273(100)$ & $244(89.4)$ & $29(10.6)$
\end{tabular}

Highest rates of seropositivity to rubella observed among age group $\geq 40$ years supports earlier suggestion that longer period and probably higher frequency of childbearing and nursing experienced in such age group may predispose them to greater risk of exposure and infection. Lack of protective rubella IgG antibody in 29/273 [10.6\%] of the study population and more significantly lack of detectable antibody in 9 out of the 29 women suggest existence of susceptible population for rubella virus maintenance in the community. This finding confirms earlier reports $[26,28]$ that despite the development and administration of effective vaccines for prevention and control of rubella virus infection since 1969 and prevention or elimination of the causative agent in many developed countries, cases of rubella virus infection and CRS are still being reported among diverse groups in Nigeria.

However, since humans are the only known reservoir for rubella virus, maintenance of rubella requires continuous access to a susceptible population. Therefore, an enhanced immunization programme aimed at ensuring high level of herd immunity would facilitate the control of rubella epidemics [29]. Furthermore, findings from this and previous studies in the country indicate that Nigeria has in its hands, an opportunity to eliminate the virus since the burden is low and the definite susceptible population is defined.

Rubella naive individuals are susceptible to infection, thus constitute risk of transmission and maintenance of a vaccine-preventable virus infection in the community and the world at large.
Prevention or elimination of rubella virus infection has been achieved in many developed countries with the introduction of preventive vaccine. Therefore, to facilitate prompt and effective virus elimination in the country, immediate introduction of preventive rubella vaccination to susceptible population is essential.

In conclusion, results of the study emphasize the need for establishment of an improved and continuous surveillance network for rubella infection and CRS cases; prompt vaccination of vulnerable population and periodic evaluation of health policies to guarantee immunization. Thus, to facilitate prompt elimination of rubella we recommend the establishment of health policy that promotes: (a) free vaccination programmes for children and adults of childbearing age (b) evaluation of available vaccines to ascertain their potency prior recommendation for vaccination (c) review of antibody response in randomly selected individuals post vaccination, and (d) rubella virus and CRS surveillance.

\section{ACKNOWLEDGEMENTS}

We acknowledge with gratitude, the support of the Medical Director and the entire Hospital Management Board as well as the cooperation by all participants. Author's contributions: MOA and JAA were involved in the conception and design of the study. MOA, RBO and BAO were involved in sample and data collection, analysis and interpretation of results. Manuscript preparation was by MOA, while revision of the manuscript was by MOA and JAA. 


\section{REFERENCES}

1. Cutts F.T., Robertson S.E., Diaz-Ortega J.L., Samuel R. Congenital rubella syndrome (CRS) in developing countries,

part 1: burden of disease from CRS. Bull World Health Organ 1997; 75: 55-68.

2. Chantler J., Wolinsky J.S., Tingle A. Rubella virus. In: Knipe D.M., Howley P.M. (eds). Fields Virology. New York: Lippincott Williams \& Wilkins, 2001: 963-991.

3. Lambert H.P., Stern H., Wellsteed A.J. Congenital rubella syndrome. Lancet $1965 ; 2: 826-827$.

4. Antia A.U. Congenital heart disease in nigeria: clinical and necropsy study of 260 cases. Archives of disease in childhood 1974; 49:36-39.

5. Plotkin S.A. and Reef S. Rubella vaccine. In: Plotkin S.A., Orenstein W.A. (eds). Vaccines. WB Saunders Co, 2007: 707743.

6. Atreya C.D., Mohan K.V.K., Kulkarni S. Rubella virus and birth defects: molecular insights into the viral teratogenesis at the cellular level. Birth Defects Research Part A: Clinical and Molecular Teratology 2004; 70 (7):431437.

7. Elliman D., Sengupta N., El Bashir H., Bedford H. Measles, mumps, and rubella: prevention. Clinical Evidence 2007; pii:0316.

8. Gregg N. McA. Congenital cataract following german measles in the mother. Transactions of the Ophthalmological Society of Australia, 1941; 3:35-46.

9. Frey T.K. Molecular biology of rubella virus. Advances in Virus Research. 1994; 44:64-159.

10. Lee J.Y., Bowden D.S. Rubella virus replication and links to teratogenicity. Clinical Microbiology Reviews 2000; 13:571-587.

11. World Health Organization Report of a meeting on preventing congenital rubella syndrome: immunization strategies, surveillance needs. www.who.int/vaccinesdocuments/Docs PDF00/www508.pdf. 2000.

12. Robertson S.E., Featherstone D.A., GacicDobo M., Hersh B.S. Rubella and congenital rubella syndrome: global update. Revista Panamericana de Salud Publica 2003; 14(5).

13. Böttiger M., Forsgren M. Twenty years' experience of rubella vaccination in sweden: 10 years of selective vaccination (of 12-year-old girls and of women postpartum) and 13 years of a general two-dose vaccination. Vaccine, 1997; 15(14):1538-44.

14. Cutts F.T., Vynnycky E. Modelling the incidence of congenital rubella syndrome in developing countries. International Journal of Epidemiology 1999; 28(6):1176-84

15. Su S.B. and Guo H.R. Seroprevalence of rubella among women of childbearing age in Taiwan after nationwide vaccination. The American Journal of Tropical Medicine and Hygiene. 2002; 67(5):549-53.

16. Malakmadze N., Zimmerman L.A., Uzicanin A., Shteinke L., Caceres V.M. Kasymbekova K. Development of a rubella vaccination strategy: contribution of a rubella susceptibility study of women of childbearing age in Kyrgyzstan, 2001. Clinical Infectious Diseases 2004; 38(12):1780-3.

17. Dwyer D.E., Robertson P.W., Field P.R. Broadsheet: clinical and laboratory features of rubella. Pathology. 2001; 33:322-328.

18. Webster W.S. Teratogen update: congenital rubella. Teratology. 1998; 58:13-23.

19. Castillo-Solorzano $C$ and Andrus J.K. Rubella elimination and improving health care for women. Emerging Infectious Diseases, 2004; 10(11):20172021.

20. Odelola H.A., Fabiyi A., Familusi J.B. Distribution of rubella antibodies in nigeria. Transactions of the Royal Society of Tropical Medicine and Hygiene. 1977; 71(5):425-426.

21. Onyenekwe C.C., Kehinde-Agbeyangi T.A., Ofor U.S., Arinola O.G. Prevalence of rubella-IgG antibody in women of childbearing age in lagos, nigeria. West African Journal of Medicine. 2000; 19(1):23-6.

22. Bamgboye A.E., Afolabi K.A., Esumeh F.I., Enweani I.B. Prevalence of rubella antibody in pregnant women in ibadan, nigeria. West African Journal of Medicine. 2004; 23(3):245-8.

23. Adesina O.A., Adeniji J.A., Adeoti M.O. Rubella IgG antibody in women of childbearing age in oyo state. African Journal of Clinical and Experimental Microbiology, 2008; 9(2):78-81.

24. Mohammed-Durosinlorun A., Shittu O., Sadauki H., Olayinka A., Kolawole B. Adejo D. Prevalence of rubella IgG 
antibodies among pregnant women in zaria, nigeria International Health 2010; 2(2):156-159.

25. Bukbuk D.N., el Nafaty A.U., Obed J.Y. Prevalence of rubella-specific IgG antibody in non-immunized pregnant women in maiduguri, north eastern nigeria. Central European Journal of Public Health, 2002; 10(1-2):21-3.

26. Pennap G., Amauche G., Ajoge H., Gabadi S., Agwale S., Forbi J. Serologic Survey of specific rubella virus IgM in the sera of pregnant women in Makurdi, Benue state, nigeria. African Journal of Reproductive Health 2009; 13(2):69-73.

27. White D.O. and Fenner F.J. Togaviridae. In: Medical Virology, $4^{\text {th }}$ Edition Academic Press, California: USA, 1994: 418-433.
28. Olusanya O., Blomberg J. Antibody prevalence against rubella among hospital personnel in nigeria: implications for health care system and immunisation policy. Acta Tropica, 1990; 48(2):101-107.

29. Vyse A.I., Gay N.I., White J.M., Ramsay M.E., Brown D.W., Cohen B.J. Evolution of surveillance of measles, mumps, and rubella in England and Wales: providing the platform for evidence-based vaccination policy. Epidemiologic Reviews 2002; 24(2):125-136. 